\title{
RISK ASSESSMENT OF THE AIR POLLUTION FOR INDUSTRIAL \& RESIDENTIAL AREA CASE STUDY: EL-MAX AREA, ALEXANDRIA CITY
}

Ashraf M. SAbdul Malek ${ }^{1}$; Zahran, A. H. ${ }^{1}$; and El-Hattab, M. M. ${ }^{1}$

Environmental Studies and Researches Institute, University of Sadat City

\section{ABSTRACT:}

his papers introduces the concept of air pollution risk assessment (APRA) or

$\mathrm{T}$ health risk assessment (AP-HRA), describes in broad terms how the health risks of outdoor air pollution and its sources are estimated, and gives an overview of the general principles for the proper conduct of an AP-HRA for various scenarios and purposes (WHO, 2006) $)^{(1)}$

The main purpose of an AP-HRA is to estimate and communicate the health impact of exposure to air pollution or changes in air pollution in different socioeconomic, environmental, and policy circumstances.

The first step of an AP-HRA is to assess the exposure of the target population to specific air pollutants. Monitoring data may be used to estimate the past and current exposure to air pollution for populations living near the monitoring site. In addition, air quality modelling is often used to estimate differences in exposure for different socioeconomic and environmental conditions within the geographical area of interest, and to predict changes in exposure in future policy scenarios. The second step of an AP-HRA is to estimate the health risk associated with the exposure to air pollution. This requires the use of concentration-response functions (CRFs), which quantify the health impact per concentration unit of a particular air pollutant. The third step of an AP-HRA is to quantify and express the uncertainty of the generated estimate of health impact. This is an important and integral component of the results, and it is vital to ensure both that the main message is not lost and that the results produced are understandable by policy-makers and others who do not necessarily have a technical background or expertise in AP-HRA.

Results of AP-HRAs are often reported in terms of numbers of attributable deaths or cases of disease, years of life lost, disability-adjusted life years, or change in life expectancy attributable to exposure or a change in exposure to air pollution. These health impacts can then be used to evaluate costs and benefits of policy change in monetary terms.

Key Words: Air Pollution, Risk Assessment, Alexandria.

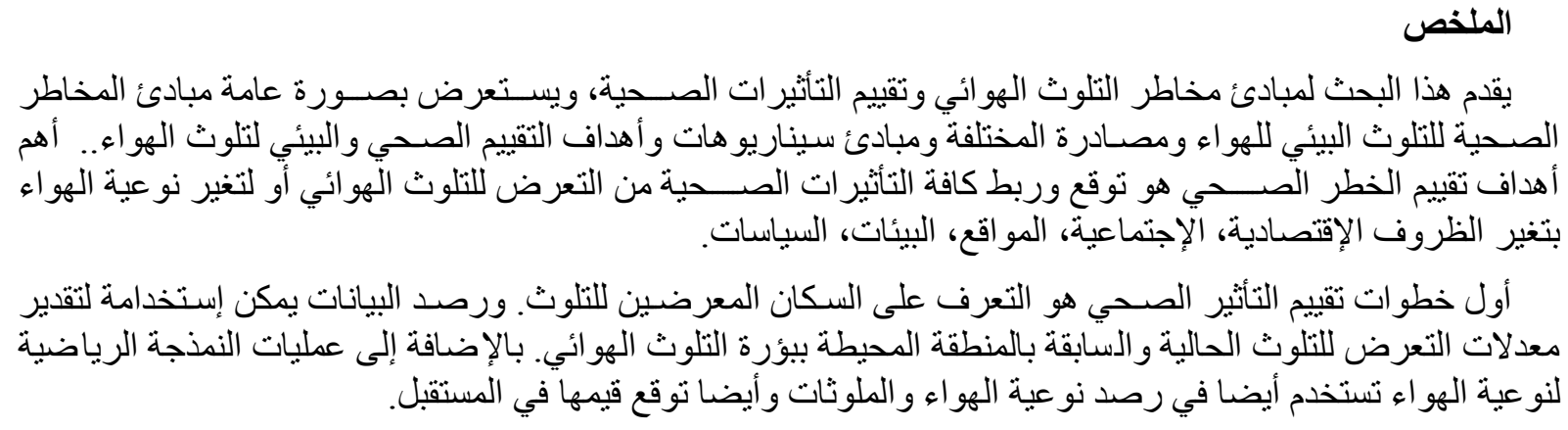

Issued by Environmental Studies and Researches Institute (ESRI), University of Sadat City 


$$
\begin{aligned}
& \text { ثاني خطو ات تقييم التأثثر الصحي هو تقييم مدى الخطورة الصحية الناجمة عن التعرض لملوثات الهواء في بيئة معينة. }
\end{aligned}
$$

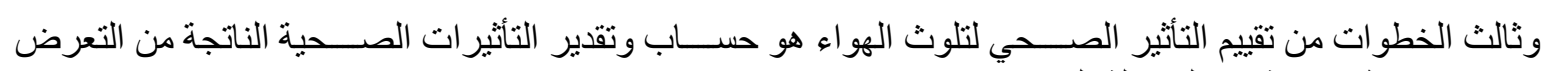

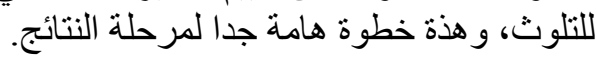

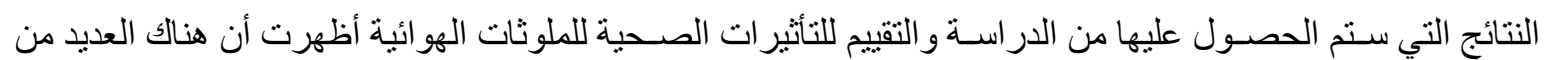

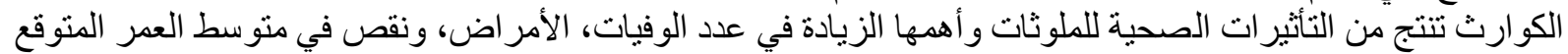

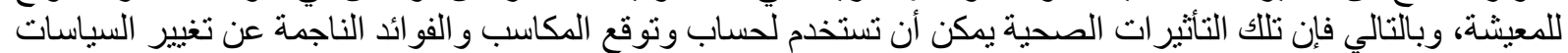

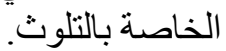

\section{INTRODUCTION:}

In many countries, an AP-HRA is formally required as part of the decisionmaking process for new programs, projects, regulations, or policies that potentially have an effect on air quality. The assessments were previously limited to qualitative descriptions; scientific advances are now allowing more detailed quantitative analyses of the health risks of air pollution. The industrial activities are expected to discharge their wastes to the surrounding atmosphere. Therefore, monitoring and assessment should be done to manage and control the air pollution. On the other hand, geographical information system (GIS) is an important tool used in environmental management to support integrated pollution prevention and control. Program for air pollution management and control must be established to increase the awareness of health, economic impacts, and help the tourism sector.

In this papers, problem definition, a survey of measurements of various types of air pollution (TSP, PM10, and PM2.5) and calculate of the risk of these pollutants in industrial (stack of cement company) and residential area (ambient) in El Max area as a case study in Alexandria will be carried out. All these data will be carried out in a geographical map by using GIS technique.

Pollution in ambient air is generally a complex mixture. Consequently, the adverse health impacts observed in epidemiological studies and attributed to an individual air pollutant may actually be partly due to other pollutants in the mixture. PM may be characterized in terms of the mass concentration of particles smaller than $2.5 \mu \mathrm{m}\left(\mathrm{PM}_{2.5}\right)$ or $10 \mu \mathrm{m}\left(\mathrm{PM}_{10}\right)$, the number of particles (ultrafine), or the chemical composition (e.g. black carbon, organic compounds and heavy metals). Epidemiological and toxicological evidence shows that $\mathrm{PM}$ mass $\left(\mathrm{PM}_{2.5}, \mathrm{PM}_{10}\right)$ comprises fractions with varying types and degrees of health effects (WHO Regional Office for Europe, 2013). ${ }^{(2)}$

$\mathrm{PM}_{10}$ may be an appropriate indicator when considering the impact of resuspension of road dust, while black carbon is a more sensitive indicator for exhaust emissions from road traffic (Keuken et al., 2012). ${ }^{(3)}$

$\mathrm{PM}_{2.5}$ has been investigated in many epidemiological studies, and has been shown to be a robust indicator of risk associated with exposure to PM from diverse sources and in different environments (Lim et al., 2013). ${ }^{(4)}$

The area of study is El-Max zone in Alexandria City. This area contains six different land uses, illustrated in the next Table and Figure. 
Journal of Environmental Studies and Researches (2017)

\begin{tabular}{|c|c|}
\hline No. & Land Use \\
\hline 1 & Alexandria for Petroleum Co. \\
\hline 2 & Alexandria Portland Cement Co. \\
\hline 3 & Misr Chemical Industries Co. (MCI) \\
\hline 4 & Alexandria Mineral Oils Co. (AMOC) \\
\hline 5 & Alexandria National Refining and Petrochemicals Co. (ANRPC) \\
\hline 6 & Residential Areas \\
\hline
\end{tabular}

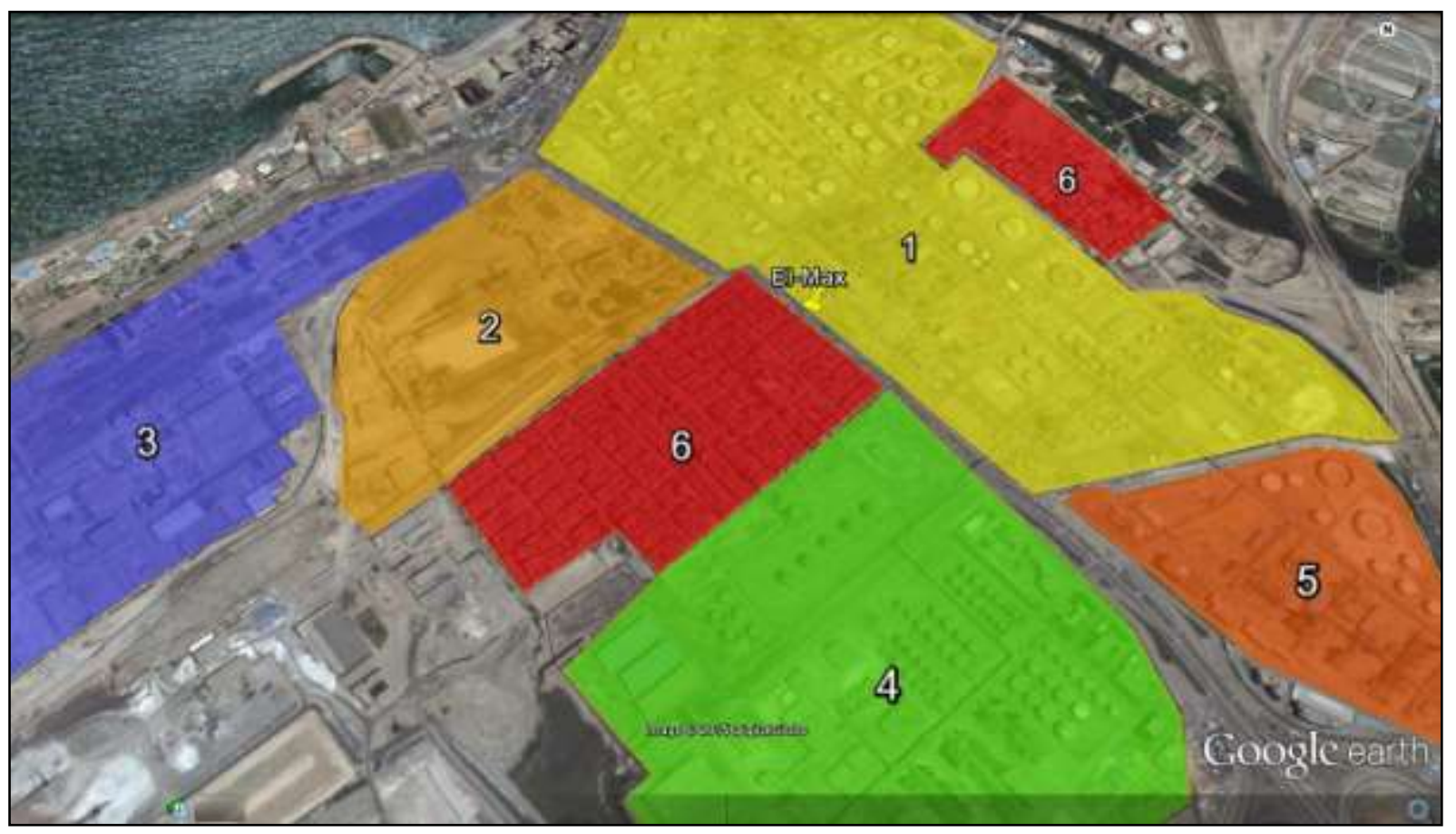

Figure (1) Different land uses in the study Area.

\section{HEALTH RISK ASSESSMENT (HRA)}

a health risk assessment is the scientific evaluation of potential adverse health effects resulting from human exposure to a particular hazard. The health hazard of interest is air pollution.

\section{AN AP-HRA MAY BE QUANTITATIVE OR QUALITATIVE; IT GENERALLY ASSESSES}

(i) The amount of air pollution present, i.e. pollutant concentrations,

(ii) The amount of contact (exposure) of the targeted population,

(iii) How harmful the concentration is for human health, i.e. the resulting health risks to the exposed population $(\mathrm{WHO}, 2010)^{(5)}$. 


\section{RISK ASSESSMENT}

Risk assessment is one tool used in risk management. It is the process that scientists and government officials use to estimate the increased risk of health problems in people who are exposed to different amounts of toxic substances. Also Risk assessment is the determination of quantitative or qualitative estimate of risk related to a well-defined situation and a recognized threat (hazard).

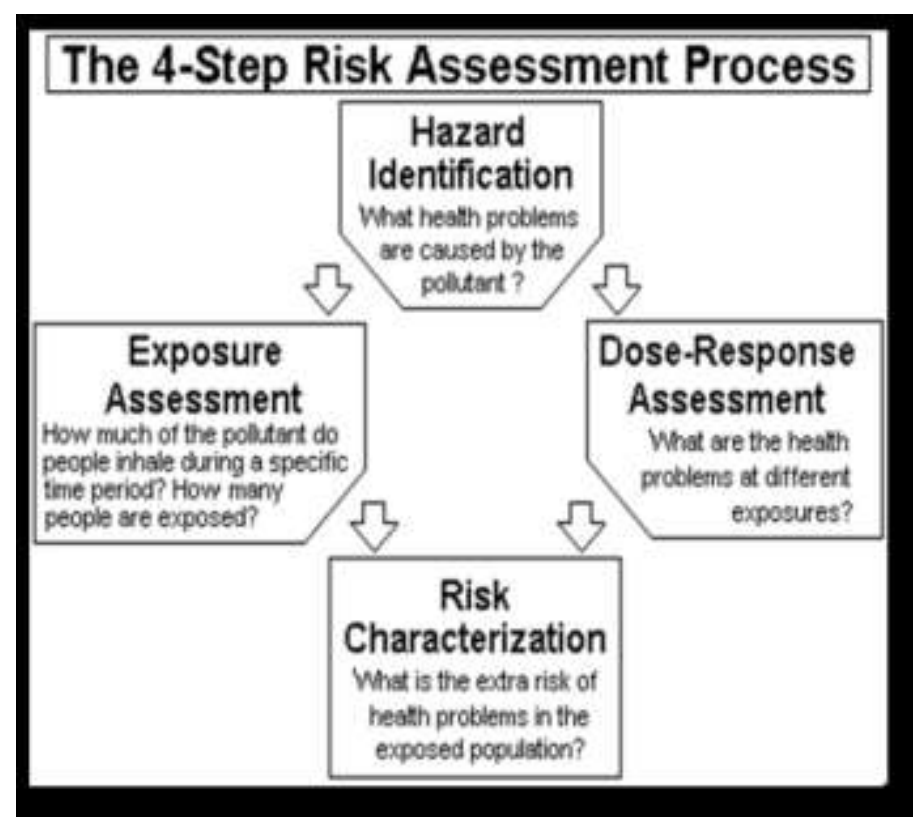

Figure (2): The 4 steps Risk Assessment Process

Quantitative risk assessment requires calculations of two components of risk (R): the magnitude of the potential loss (L), and the probability (p) that the loss will occur. An acceptable risk is a risk that is understood and tolerated usually because the cost or difficulty of implementing an effective countermeasure for the associated vulnerability exceeds the expectation of loss.

\section{Risk $=($ Probability of the accident occurring). (Expected Loss)}

Health risk assessment" includes variations, such as risk as the type and severity of response, with or without a probabilistic context. ${ }^{(6)}$

\section{MEASUREMENTS AND RISK CATEGORIES OF AIR POLLUTANTS}

The measurements of TSP, $\mathrm{PM}_{10}, \mathrm{PM}_{2.5 \text { in }}$ the ambient throughout the period of 12 months from January 2016 to December 2016 are shown in table (1). 
Table (1): Concentration of TSP, PM10. And PM2.5 $\mu \mathrm{g} / \mathrm{m}^{3}$ at El Max area (Ambient), 2016

\begin{tabular}{|c|c|c|c|}
\hline \multirow{2}{*}{ Month } & \multicolumn{3}{|c|}{ Air Pollutants (TSP, PM10. And PM2.5 $\boldsymbol{\mu g} / \mathbf{m}^{\mathbf{3}}$ ) } \\
\cline { 2 - 4 } & $\mathbf{T S P}$ & $\mathbf{P M}_{\mathbf{1 0}}$ & $\mathbf{P M}_{\mathbf{2 . 5}}$ \\
\hline \multirow{2}{*}{ AQL (24 hrs) } & $\mathbf{2 3 0}$ & $\mathbf{1 5 0}$ & $\mathbf{1 0 0}$ \\
\hline AQL (annul) & $\mathbf{1 2 5}$ & $\mathbf{1 0 0}$ & $\mathbf{7 0}$ \\
\hline Jan & 357 & 142.8 & 85.7 \\
\hline Feb & 315 & 126.0 & 75.6 \\
\hline March & 336 & 134.4 & 80.6 \\
\hline Apr & 301 & 120.4 & 72.2 \\
\hline May & 266 & 106.4 & 63.8 \\
\hline June & 198.8 & 79.5 & 47.7 \\
\hline Juley & 281.4 & 112.6 & 67.5 \\
\hline August & 358.4 & 143.4 & 86.0 \\
\hline Sept & 340.9 & 136.4 & 81.8 \\
\hline Oct & 372.4 & 149.0 & 89.4 \\
\hline Nov. & 297.5 & 119.0 & 71.4 \\
\hline Dec. & 427 & 170.8 & 102.5 \\
\hline
\end{tabular}

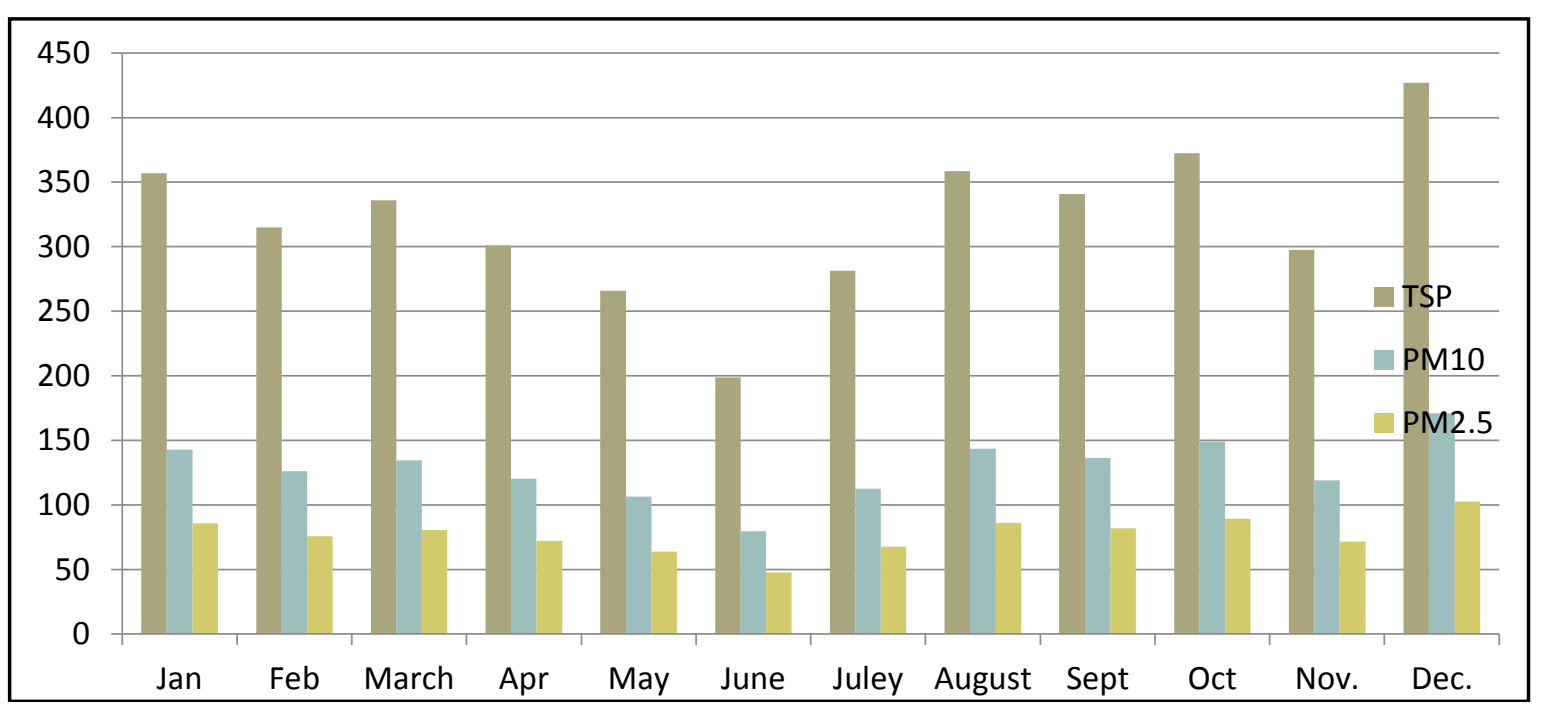

Figure (3): Concentration of TSP, PM10. And PM2.5 $\mu \mathrm{g} / \mathrm{m}^{3}$ at El Max area (Ambient), 2016 
To assess the risk according to the law 9/2009, I was supposed that the quantity $100 \mathrm{mg} / \mathrm{m}^{3}$ of TSP is the maximum permissible limit for the stack and above this value will be the beginning of the risk. AQL will be better when the TSP value is less than $100 \mathrm{mg} / \mathrm{m}^{3}$, and the risk category will be decrease with decreasing the value of TSP as mentioned in table (2), and respectively, the impact on the health will minimize.

By the same manner, the idea will apply with $\mathrm{PM}_{10}$ and $\mathrm{PM}_{2.5}$ as shown in tables $(3,4)$

$\mathrm{AQL}=$ Risk limit

More than AQL will be risky in all types of air pollutants (TSP, PM10 and $\mathrm{PM}_{2.5}$ ).

Table (2): The AQL and suggested Risk categories of the concentration of TSP from ambient in 24 hrs

\begin{tabular}{|c|c|c|c|}
\hline $\begin{array}{c}\text { AQL for TSP } \\
\text { from ambient } \\
\text { according to Law } \\
\text { 9 for 2009 }\end{array}$ & $\begin{array}{c}\text { \% categories } \\
\text { according to AQL }\end{array}$ & $\begin{array}{c}\text { Value of law } \\
\text { according to } \\
\text { categories }\end{array}$ & Risk Categories \\
\hline \multirow{3}{*}{$230 \mu \mathrm{g} / \mathrm{m} 324 \mathrm{hrs}$} & $0-20$ & $0-46$ & A ( no risk) the best category \\
\cline { 2 - 4 } & $21-40$ & $47-92$ & B ( no risk) good category \\
\cline { 2 - 4 } & $41-60$ & $93-138$ & C ( no risk) the better category \\
\cline { 2 - 4 } & $61-80$ & $139-184$ & D ( no risk) the moderate category \\
\cline { 2 - 4 } & $81-100$ & $185-230$ & E (risk limit) \\
\hline
\end{tabular}

Table (3): The suggested risk categories of the concentration of PM2.5 in the ambient in $24 \mathrm{hrs}$

\begin{tabular}{|c|c|c|c|}
\hline $\begin{array}{c}\text { AQL for PM2.5 } \\
\text { from ambient } \\
\text { according to Law } \\
\text { 9 for 2009 }\end{array}$ & $\begin{array}{c}\text { \% categories } \\
\text { according to AQL }\end{array}$ & $\begin{array}{c}\text { Value of law } \\
\text { according to } \\
\text { categories }\end{array}$ & Risk Categories \\
\hline \multirow{3}{*}{$100 \mu \mathrm{g} / \mathrm{m} 324 \mathrm{hrs}$} & $0-20$ & $0-20$ & A ( no risk) the best category \\
\cline { 2 - 4 } & $21-40$ & $21-40$ & B ( no risk) good category \\
\cline { 2 - 4 } & $41-60$ & $41-60$ & C ( no risk) the better category \\
\cline { 2 - 4 } & $61-80$ & $61-80$ & D ( no risk) the moderate category \\
\cline { 2 - 4 } & $81-100$ & $81-100$ & E (risk limit) \\
\hline
\end{tabular}

Table (4): The risk Categories of the concentration of $\mathrm{PM}_{10}$ from ambient in $24 \mathrm{hrs}$ 


\begin{tabular}{|c|c|c|l|}
\hline $\begin{array}{c}\text { AQL for PM10 from } \\
\text { ambient according to } \\
\text { Law 9 for 2009 }\end{array}$ & $\begin{array}{c}\text { \% categories } \\
\text { according to AQL }\end{array}$ & $\begin{array}{c}\text { Value of law } \\
\text { according to } \\
\text { categories mg/m3 }\end{array}$ & \multicolumn{1}{|c|}{ Risk Categories } \\
\hline \multirow{3}{*}{$150 \mu \mathrm{g} / \mathrm{m} 324 \mathrm{hrs}$} & $0-20$ & $0-30$ & $\begin{array}{l}\text { A (no risk) the best } \\
\text { category }\end{array}$ \\
\cline { 2 - 4 } & $21-40$ & $31-60$ & B (no risk) good category \\
\cline { 2 - 4 } & $41-60$ & $61-75$ & $\begin{array}{l}\text { C ( no risk) the better } \\
\text { category }\end{array}$ \\
\cline { 2 - 4 } & $61-80$ & $76-90$ & $\begin{array}{l}\text { D (no risk) the moderate } \\
\text { category }\end{array}$ \\
\cline { 2 - 4 } & $81-100$ & $91-150$ & E (risk limit) \\
\cline { 2 - 4 } & $>100$ & $>150$ & F (Risky) \\
\hline
\end{tabular}

Table (5): The risk of the concentration of TSP from ambient in $24 \mathrm{hrs}$ and annually

\begin{tabular}{|c|c|c|c|c|c|}
\hline Month/ year & $\begin{array}{l}\text { Ambient TSP } \\
\text { Conc. } \mu \mathrm{g} / \mathrm{m}\end{array}$ & $\begin{array}{c}\text { \%categories } \\
\text { according to AQL }\end{array}$ & $\begin{array}{c}\text { Risk } \\
\text { Categories }\end{array}$ & $\begin{array}{c}\% \text { categories } \\
\text { according to AQL }\end{array}$ & $\begin{array}{c}\text { Risk } \\
\text { Categories }\end{array}$ \\
\hline & \multicolumn{3}{|c|}{24 hours 230} & \multicolumn{2}{|c|}{ Annual125 } \\
\hline Jan & 357 & 155.2 & $\mathrm{~F}$ & 285.6 & $\mathrm{~F}$ \\
\hline Feb & 315 & 137 & $\mathrm{~F}$ & 252 & $\mathrm{~F}$ \\
\hline March & 336 & 146 & $\mathrm{~F}$ & 268.8 & $\mathrm{~F}$ \\
\hline April & 301 & 130.9 & $\mathrm{~F}$ & 240.8 & $\mathrm{~F}$ \\
\hline May & 266 & 115.6 & $\mathrm{~F}$ & 212.8 & $\mathrm{~F}$ \\
\hline June & 198.8 & 86.4 & $\mathrm{E}$ & 159 & $\mathrm{~F}$ \\
\hline July & 281.4 & 122.3 & $\mathrm{~F}$ & 225.1 & $\mathrm{~F}$ \\
\hline August & 358.4 & 155.8 & $\mathrm{~F}$ & 286.7 & $\mathrm{~F}$ \\
\hline Sept. & 340.9 & 148.2 & $\mathrm{~F}$ & 272.7 & $\mathrm{~F}$ \\
\hline Oct. & 372.4 & 161.9 & $\mathrm{~F}$ & 297.9 & $\mathrm{~F}$ \\
\hline Nov. & 297.5 & 129.3 & $\mathrm{~F}$ & 238 & $\mathrm{~F}$ \\
\hline Dec. & 427 & 185.6 & $\mathrm{~F}$ & 341.6 & $\mathrm{~F}$ \\
\hline
\end{tabular}

From the above tables, found that, the percentages of TSP measured values to the AQL value in low 94/1994 are very high in all the year 2016 from January to December, and then, the risk category is (F) which is risky category. the exposure to

$$
r \cdot 9
$$


this level of risk or TSP values ( in both $24 \mathrm{hrs}$. and annually AQL) will lead to upper and lower respiratory system diseases and also cardiovascular diseases and may cause lung cancer .

\section{REFERENCES:}

1. WHO Regional Office for Europe (2006) Air quality guidelines for particular matter, ozone, nitrogen dioxide and sulphur dioxide. Global update 2005. Copenhagen.

2. WHO Regional Office for Europe (2013). Review of evidence on health aspects of air pollution (REVIHAAP). Technical report. Copenhagen.

3. Keuken MP et al. (2012) Elemental carbon as an indicator for evaluating the impact of traffic measures on air quality and health. Atmospheric environment, 61: 1-8.

4. Lim SS et al. (2013) A comparative risk assessment of burden of disease and injury attributable to 67 risk factors and risk factor clusters in 21 regions, 19902010: a systematic analysis for the Global Burden of

5. 10.WHO (2010) WHO human health risk assessment toolkit: chemical hazards. IPCS harmonization project document; no.8. Geneva; World Health Organization

6. https://en.wikipedia.org/wiki/Risk_assessment. 